\title{
Facebook as Space of Resistance for Indonesian-Postcolonial Identity
}

\author{
Kandi Aryani Suwito \\ Communication Department, Universitas Airlangga, Indonesia \\ Email: kandee aryani@yahoo.com, kandisuwito@gmail.com
}

DOI:10.5901/mjss.2014.v5n22p82

\begin{abstract}
This paper aims to answer the problem of how Facebook functions to re-construct the Indonesian-postcolonial identity by means of narrative in marking the transition from colonized subjects to liberated beings. The reason why colonial discourse still dominates modern society is due to its ability to possibly re-generate the feeling of inferiority in native culture and perpetuate the patterns of behaviour even after the era of colonialism was over. Evidently, the coming of Internet in Indonesia is significant and highly relevant to postcolonial study only if it is grasped in relation to the preceding history of Indonesian 'old' media. If Internet is socially imagined as a powerful tool of opposition to authoritarianism, I will show how Facebook makes room for a voice of disapproval of the dominant systems and create an independent surveillance over state, opening up unconstrained participation of people who are used to live under authoritarian regimes. My analysis will be focused on the way Facebook provides a mechanism to formulate a 'new' community that hold power to form a collective struggle of those who were considered as the 'other' - the ones formerly excluded or marginalized from the oppressive discourse. Certain ideas are liberally spread out in Facebook, creating an unstoppable flow of resistance toward the dominant discourse and changing the face of the nation. I see narrative as the ideological apparatus that seeks to liberate marginalized subjects by giving them the power to interpret their own experience and subjectivity without conforming to the dominant discourse. The medium is now giving a sense of pleasure and fascination in designing the conception of being a free agent. The process of self-identification produces acts of contestation by making clear the fact that identity is historically unstable and an object of change and reconstruction.
\end{abstract}

Keywords: Identity, Narrative, Resistance, Postcolonial, the Other, Facebook

\section{Introduction}

Having suffered colonial domination and oppression for hundreds of years, Indonesia is struggling with the idea of being a nation in contemporary society. Even though the colonial period has ended, the colonial discourse remains and gives shape to anti-colonialist debates in the post-colonialist era which is materialized in the huge range of issues that shows the problematic concept of post-colonialism itself. The emergence of new media appears as a new area of enquiry within the discourse of post-colonialism and the problem of agency is the specific issue I focus on. The question of identity is central within postcolonial theories. It also has a considerable impact on the study of media. Postcolonial theories are continuously struggling with the idea of 'culture' especially when they claim to speak from the position of the marginal or the silenced. It means that these theories will always deal with identity as a construct, shaped and continuously transformed within new cultural conditions. The notion of agency is important in my thesis since I will scrutinize how identity under postcolonial discourse needs to be re-situated within the emergence of new media that put forward the political economy of signs as an inevitable part of hyper-capitalism. Thus globalization will never leave individuals free without trying to transform them as commodity. As the notion of power has unquestionably characterized the postcolonial discourse, it is interesting to see how new media have acted as an apparatus that bring the power of consumption as a means of understanding oneself. For this reason, my thesis is certainly an interdisciplinary study, positioning identity in contradiction - as an active agent that makes the most of new media but also nothing but a coded object materializing as an image.

Defined by anything but the West, Indonesia, which is living with the history of a former colonized country, was politically positioned to comply with the fate of being the 'Other'. Therefore, the notion of colonialism in this paper will be scrutinized within the discourse of Orientalism which gives a crucial impact in constructing the binary opposition of the Orient (the East) and the Occident (the West) in the contemporary system of representation. Said's thesis about Orientalism will be best in making clear that the Orient is not a natural condition - rather a construction made in order to support the authoritative position of the West, a western style for dominating, restructuring, and having authority over the Orient (Said, 1978; 3). The 
binary opposition the Orient - the Occident is not simply produced without involving a structured political domination between engaged parties.

While I focus my paper on the representational domain, I am fully aware that the relevance of postcolonial studies remains central. Its heterogeneous inter-disciplinary nature opens up diverse meanings and implications of the term 'postcolonialism'. The question of superiority and inferiority in the production of knowledge is mostly evident in the process of naming as it implies the power relation between the dominant and the dominated. A contemporary study on postcolonialism should take a specific case that illustrates the mechanism though which the former discourse of colonialism has been challenged by the emergence of new media as colonialism had deployed diverse strategies and methods of control and representation (Loomba, 1998; 19). As Orientalism proposes imaginative assumption about what Orient is, it is necessary to see how the so-called 'Orient' produces text about 'the self' instead of just becoming a fabricated construct, manufactured by the West. Therefore, the scope of my analysis in this chapter will be limited to answer the question whether the Indonesian-Orient can liberate themselves from the logic of subjugation and domination or reinforce the assumptions/stereotypes posed by the West to the Orient.

I will advance my analysis by bringing the identity of the Orient into light pertaining to the problematical conception of agency in the virtual domain. Participatory culture as suggested by Jenkins has made it possible for the average consumers to archive, appropriate and re-circulate media content in powerful new ways (Jenkins, 2009; 8). Hence, it is hard to consent with Fernandez who says that postcolonial studies has a very few points of intersection (Fernandez, 1999; 59). Quite the contrary, key postcolonial issues, such as identity, representation, agency, gender, power and space have been inherently assigned to the new media discourse.

I have chosen Facebook as a specific case relating to the idea of agency, because during its rather short existence this social networking site has become the top-ranked site in Indonesia, beating Yahoo and Google.1 This fact was published in The Sidney Morning Herald and this news story triggered some debates among local religious groups, responding to the popularity of Facebook with accusations of spreading lies and gossips. When The Sidney Morning Herald announced about the popularity of Facebook in Indonesia, the article acknowledged Facebook as a current phenomenon, dictating public actions. In the article in this online newspaper, Facebook has been accused for strongly arousing moral indulgence, enabling people to exploit this site in an inappropriate manner. Facebook even brought together Indonesian Muslim clerics to come together and criticize the existence of this social networking site that has successfully attracted around 1-2 million people and makes Indonesia the fastest growing country on Facebook in Southeast Asia.2 About 700 Muslim clerics agreed and decided that Facebook is forbidden if it is used for spreading lies, gossips and sexual content, even though this edict did not carry any legal weight. The involvement of religious groups in the evaluation of Facebook has opened up a valuable debate about the meaning of technology for human experience and the consequences of adapting 'the self' in technoculture, where identity is judged by the way individuals relate themselves to technology.

If technology continues to penetrate everyday life, it is understandable to worry about its capability to dominate both private and public spheres and challenge what was considered to be traditional values. Facebook can probably be perceived as seduction, provoking people to consume more texts and explore all the possibilities of what the medium can do. The seductive nature of the medium might also be the reason why the local government in Surabaya, the second biggest city in Indonesia, block access to Facebook and two other social networking sites for their employees during the office hours, arguing that civil servants, working for the local government, have wasted too much time using these services. 3 What is it on Facebook that creates fascination and dread at the same time, establishes link between human and machine, fuses the real and the virtual in the new realm of reality', based on self-production and participation? This 'new reality' is the subject of my thesis which also bring me to examine how Facebook has promoted a space for resistance to the dominant ways of seeing by welcoming the users to create their own narratives and contribute to the definition of the new media.

New media now appear as a contemporary colonial discourse that works through the specific rhetoric, engaging people in a voluntary support of the imperialist projects. Facebook is a virtual world industry, an economic-oriented space intended to be the market leader in the real world. Sign becomes a commodity by generating 'needs' and offering a sense of

\footnotetext{
1 http://www.smh.com.au/world/indonesia-gives-Facebook-the-nod-but-no-flirting-please-20090522-bi9v.html. Retrieved:10-09-2009

2 http://www.smh.com.au/world/indonesia-gives-Facebook-the-nod-but-no-flirting-please-20090522-bi9v.html \& http://globalvoicesonline.org/2009/01/11/indonesia-Facebook-users-on-the-rise/. Retrieved: 10-09-2009

3http://www.smh.com.au/technology/technology-news/Facebook-blocked-for-indonesia-city-employees-official-20090911-fitt.html. Retrieved: 10-09-2009
} 
individuality. The parade of images on Facebook reveals the fact that key categories of colonialism have been incorporated into the global market. Virtual commodities are linked with the actual substance, which distort the assumed border, dividing the virtual from the actual, which might not have actually existed before. It is intriguing to see how Facebook as a medium has captured the 'real self' and turned it into a sign that refers to 'the self'. At this point it is hard to recognize which one can be considered 'the real self', since this digital apparatus replaces the real subject with an object. If this is the case, I wonder if Facebook has actually put an end to the notion of 'the subject'.

This makes me think that there is still a question that has not been answered adequately yet, namely, how the agency of the self should be re-positioned in the tension between the sovereign power of the subject, making the production of knowledge possible through re-narration, and the supremacy of the objects that forcefully transform any matters into signs? I believe that postcolonial studies need to be rethought within the political economy of signs, because colonialism is manifest in numerous different institutional and cultural practices. If this is the case, then I believe that the analysis of Facebook within the Indonesian context will produce a valuable study on how new media studies and postcolonial theory can mutually collaborate to tackle the challenge in incorporating the postcolonial subject not merely within a system of representation, but also by dealing with the propensity of the medium to absorb the content and question the supremacy of 'the subjects'. I will focus my analysis on the specificity of Facebook as the medium which brings the relation between the material and the ideological to light. The aptitude of Facebook will be elaborated to demonstrate the way postcolonial subjects represent themselves and are now responsible for their own images.

I will consider Facebook as narrative machine that provides freedom for users not only to relocate their world into texts within the realm of representation, but also to actually create the world in which the notion of agency manifests through the interpretation of events, without probing whether the events are real or imaginary. Rather I locate users' narratives within the social, cultural and historical frame in order to trace how Facebook gives form and mechanism for the reconstruction of the postcolonial subject. My research will explore the nature of Facebook and how it functions within the larger context of modern Indonesia. This thesis will define and typify what exactly within Facebook gives raise to the idea of the transformation of the colonized subjects into liberated beings in the contested sphere of the digital media. It is crucial to note that the agency of the self is placed in the paradox of having an ability to create narratives and being commodified as a system of sign at the same time.

Moreover, this thesis will also draw attention to the way new media possibly create a new form of narrative caused by its digital materiality - not simply technological, but also ideological. Considering narratives not only in terms of what they say or mean, but also in terms of what they do (Bassett, 2007; 41), I will closely delve into Facebook to give an idea on how postcolonial identity can be historically made and challenged by unmasking the work of new media as means to provide the subjects with a space to articulate their past and present, as well as organize their experience and make it meaningful to them. I will take Ricoeur's viewpoint that corresponds with Wittgenstein who says that the meaning of human existence is itself a narrative (Bassett, 2007; 27). By considering Facebook as a space allowing users to rethink current cultural moment, my analysis will be aimed to ask how new forms and elements of narratives evident in Facebook show that the relation between human and machine enables to rethink and reconstruct the agency of subject through the process of production and interpretation of texts. At this point, I depart from the premise that material reality exists outside Facebook, even though it can not be assured whether the narrative has been based on the real or imaginary events. What will be considered as 'the real' is everything that has been documented on Facebook, a cultural artifact that plays with three different principles of narrative discourse - mythic, historical and fictional (Ricoeur in White, 1987; 170). I attempt to uncover how the relation between these three principles turn human experience into signs, which possibly happens through human agents, active subjects and their quest for the meaning in their life.

\section{Method}

In order to produce critical insights for answer to the main research question this thesis is developed by investigating how the theoretical frameworks function throughout my analysis. I will draw on web sphere analysis and cybercultural studies to capture the means, patterns, artifacts, and mechanisms on Facebook with the intention to explore how postcolonial identities are reproduced through the relationship between the nature of Facebook as a medium and as a form of narrative, formed by abundant content produced by its users. My analysis is based on an understanding that Facebook brings about the problematical nature of the narrative in the digital age, since the process of remediation from old to new media has challenged the narrative's centrality and makes various forms of signs pervasive. 
Since web materials are time-sensitive in their nature, an attempt to capture the reproduction of postcolonial identity should include the unique mixture of ephemeral and permanent aspects of the Web. This needs to be done as I will bring together the materiality of Facebook as a medium and the text - the content produced by the users. According to Kirsten Foot, there are two aspects of the ephemerality of Web content: firstly, it is ephemeral in its transience as it can be expected to last for only a relatively brief time, but still can be viewed again at a later time; secondly, it is ephemeral in its construction where the content, once presented, needs to be reconstructed or represented in order for others to experience it (Foot in Silver \& Massanari, 2006; 90). At the same time, Foot explains that the Web has a sense of permanence which is different from its predecessors (Ibid). I agree with Foot when she says that the permanence of the Web is somewhat fleeting, since it will be regularly demolished each time it is updated by its producers. However, this concept can not be fully employed to clarify the mechanism of Facebook, as it broadly gives room for the users either to restore prior content or to remove it.

The position of the researcher should be clarified and taken into consideration in order to ensure that the research material will be properly approached and investigated by answering the proposed research question. Having said this, I will interactively engage with the objects, since the position of the researcher in the hermeneutical cycle is critical and therefore requires participant observation, whereby the researcher will be an observer and a participant at the same time. This course of action is essential for the interpretation of texts as a way to engage with postcolonial subjects and identity, which will also be claimed and taken by the author of this thesis. For this consideration, as a researcher, I will actively engage with the texts investigated. It means that I will simultaneously play with the production and consumption of the text on Facebook. This should be done as means of understanding how the relation between machine and humans is persuasively affecting the formation of identity in the digital realm. This can be achieved only if I become part of the system - as a producer, turning myself into a sign, a text, and the object of study all at once.

There are two areas on Facebook as mechanisms of self-identification that I will investigate in order to see how subjectivities are performed by the postcolonial subjects, which are: 1) identification under the profile picture where the users can narrate their identity, and 2) political views under the section 'Info'. Considering the numerous amount of information that I can get from 1132 friends on my Facebook account, I will select only several relevant narratives that show variation of data.

\section{Discussion}

\section{Re-Self-Narrating the 'Indonesian-Orient'}

As the Orient was destined to be repressed and reduced to silence, new media have emerged to promote the participatory culture that provide a way for the Orient to have their own voices articulated and expressed without restraint. But it will be premature to suggest that new media stand only for the sake of the Orient, since no arena is completely free from ideological contestation. In order to show how the 'Orient' is a contested category and problematically constructed on Facebook, I will firstly take three statements made by the users on Facebook that address the idea of colonialism.

The first statement made by Jones Batara Manurung that directly articulates his thought into words: "Against Colonialism" as a way to portray his identity. I also take a look at the second statement made by Yordan M. Batara Goa on his profile which does not straightforwardly take in the word 'colonialism': "In which there is no exploitation of man by man, there is no exploitation of man by the state, no capitalism, no poverty, no slavery, no women who desperately miserable because of the double burden". The third statement is written by Budiman Sudjatmiko: "My life is going through the agreement I have made with the conscience of humanity. If we are willing to listen, this conscience of humanity will be here, sneaking in our childhood naïve questions. My life is seeking for the answers of those childhood questions". He also describes himself in these words: "I am a Palestinian in the West Bank of Jordan river, an Aymaran-speaking Indian who lives in the city of La Paz, an Afro-American in Mississippi... fighting for freedom, justice and liberation".

Yordan has cited one of Sukarno's speeches as a way to reveal himself and Budiman Sudjatmiko was well-known as Indonesian activist and politically abused in the New Order era. It is interesting to relate Yordan's profile with the fact that Sukarno employed Communist-rhetoric in his political system 'Guided Democracy'. Sukarno's vision of the nation was based on socialism. His support for the latter stems from his advocacy of the Third World as the opposition of imperialism, where the US and Britain are seen by him as the chief international agents (Vickers; 2005; 149). This policy was the complete opposite to the New Order which returned Indonesia to a basically pro-Western and pro-capitalist development (Philpott, 2000; 164). After Sukarno was overpowered by Suharto, communism was prohibited in Indonesian society which lead to the ban of any literature or media suspected of propagating this political agenda. There was nearly no media that gave significant space for self-articulation where Indonesian citizens could freely express their own political view and put their own viewpoint into words. 
I see that the tendency of bringing the political affiliation publicly in the process of identification is made possible not only because Facebook provides the specific section about political view but also through the specificity of this medium in creating a space for 'forbidden' identity that formerly was restricted in the era of New Order and cannot be done in other kinds of media. Writing any statements that are opposed to the dominant discourse used to be considered as the act of threatening the unity of Indonesia and going up against the ruling government. The New Order effectively barred political activism and even political debate, exercising the authoritarian theory of media for the purpose of nation-building. (Sen \& Hill, 2000; 3, Kitley, 2000; 4). For me, it speaks to the fact that the emergence of new media fundamentally influences the formation and representation of the self since individuality is taking a crucial place in the media landscape.

Access to technological device is the vital thing needed to play part in the national discourse. Is the quest for hope to recover Indonesia from a long practice of colonialism finally realized by the new media? Have postcolonial subjects who are still striving to be completely free from modern colonialism worked out by indigenous people really been able to become the knowable man that can liberally perform their resistance strategically? Surprisingly, there is no word of Indonesia mentioned in these two statements and in other sections on his Facebook account. Instead of mentioning 'Indonesia', stating three other national identities all at once is his choice. At this point, narratives, symbols and rituals that constitute a sense of mutual and national belonging are something that can possibly be shared with other nations. Freedom, justice and liberation are what Budiman has in mind when he personally approaches the idea of nation, not by plainly ascribing the mutual sense of community as a nation but also positioning nationalism in the global perspective. Budiman Sudjatmiko has mentioned three different identities that both represent the trivial figure, marginalized groups of people that live in separate geographical space but share the same vision of freedom, justice and liberation. Every identity might experience the different sites of oppression, diverse ideological principles and each has to contribute to the very fundamental conception and vision of emancipation which are relevant to their unique characteristics.

The history of Indonesia is marked with violence therefore it is not surprising that most people see power as a destructive force that was frequently deemed in parallel with domination. Foucault makes a clear explanation that domination is not the essence of power and as a matter of fact, power is exercised upon the dominant as well as on the dominated; there is a process of self-formation or auto-colonization involved (Foucault in Dreyfus \& Rabinow, 1982; 186 and Smith, 2006; 100). Foucault has made it clear when he envisioned that the fundamental technical inventions and discoveries, a new technology of the exercise of power has emerged which is probably even more important than the constitutional reforms and new forms of government established at the end of the eighteenth century (Foucault, 1980; 12). Mostly, users who address the key issues of colonialism do not clearly state how colonialism can potentially be materialized in contemporary world, even for someone who explicitly states the word 'colonialism' like Jones Batara Manurung.

Articulating his thought into words: "Against Colonialism" on his Facebook account, Jones Batara Manurung stimulates a question about what colonialism means on his account when he wrote this word and how diverse forms of struggle can be brought to light in the contemporarily society. At this point, there is no such thing as an inherent meaning since the readers consciously determine the meaning of what is written. This appears with their subjectivity and makes the authority over meaning present once they start to comprehend the word (Muller, 2004; 113-114). In order to understand how this works in new media, I need to clarify that there has been a change in the social and cultural implication of writing caused by the new media..

\section{Where Am I Politically? Resistance and Power in the Digital Realm}

I choose national issues depicted in the section of 'political view' on Facebook as a space that defines the subjects not only based on their political affiliations but also their capacity to overcome the possibility of oppression. Since the beginning, the Indonesian society has struggled to deal with diversity in political agenda which has frequently been seen as a threat to Indonesian unity. This illustrates current struggle between modernity and tradition. The parade of diversity in political principle is one of the radical changes that revolutionary transform Indonesian citizens from passive subjects into the subjects of knowledge.

There are quite a lot of political views stated by the users on Facebook which never imagined to be seen publicly before without causing a problem for the subjects such as: "Left Hedonic" (by Airlangga Pribadi), "Transrational" (by Novri Susan), "No Facism" (by Jojo HateFesbuk), "Liberal" (by Eka Rahma), "Abstain" (by Kristina Lydia), "Apathetic" (Cindy Tomasoa), "Other" (Harris Abdullah), "Neutral" (Alexa Saxon), "Political What?" (Satrya Wibawa) and "Proud to be the member of People's Democratic Party" (by Tulang lyek Marpaung). I believe that a range of political views should be seen as the end of dominating and homogenous system of knowledge where individuals are not determined by dominant discourse in 
formulating and displaying their self-images. The self and the political are obviously conjoined regardless of how apolitical their statements are for whoever reads them. I know that I should retain information about the historical fact that politically relates with this word.

Convincingly testified, all those political declarations above are defending beliefs and becoming a struggle for emancipation. For me, they are arguing on the importance to keep identity heterogeneous by standing up against the Unitarian system that attempts to keep other voices but the dominant one silenced. When Kristina Lydia goes for "abstain", the political statements posed by Cindy Tomasoa have the same tone with 'abstain' as she states 'apathetic' in her profile which is also analogous with Satrya Wibawa has 'political what?' in his Facebook account. The self and the political are obviously conjoined regardless of how apolitical their statements are for whoever reads them. I know that I should retain information about the historical fact that politically relates with this word.

Refusal to vote for any parties and abstain from Indonesian politics formerly was considered as a subversive act. As a matter of fact, individuals who decline to vote in the election are called golongan putih (golput). Literally, it means 'white group', but it signifies the non-voters. Even though the values and the consequences of abstainment are still debatable, the New Order had frequently propagated a campaign against golput even though there are no laws prohibiting the Indonesian citizens to abstain. Accused of being rebellious and disrupting the public order, Indonesian citizens were politically forced to vote while there were still individuals or groups who insisted to be non-voters and considered it as a kind of political act. Among various reasons why people do not vote, golput was commonly deemed as the expression of apathy toward the government and political order in Indonesia. Astonishingly, after the New Order was over and reformation era has come forward, the total amount of golput has significantly increased. According to recent survey in Indonesian election 2009, the number of golput has approximately reached 50 millions of people or 30 percent from Indonesia's total population.1 Whoever abstained in the election can never be detected - these citizens remained anonymous, except for who choose to explicitly state political standpoint in public

\section{Performing a Nation without a Nationality}

Although Facebook is understood as a social networking site, the assumption that technology will consequentially be utilized to bring the world, strictly speaking, the others, closer than before has been challenged by a range of categories of subjectivity as it becomes harder to recognize who should be counted as the 'Other'. Facebook does not provide any section for nationality which means that this specific kind of identity categorization has been obscured and made invisible. If technology's greatest promise is to eradicate otherness as indicated by Nakamura (Nakamura, 2002; 4) and if the Orient take the chance to reveal their postcolonial identities and challenge the stereotypes projected by the West to them, how does it make their origin visible if it does not even appear on their Facebook account? It seems that the subjects on Facebook mostly use their personal social background as the basis of making a national statement to others. The fact that online world can easily be manipulated is well-understood which enables any virtual spaces to forcefully stand for their own sake and the subjects behind it.

Taking all statements, I am continuing my analysis into the point where the otherness functions well in picturing the profile of a nation with no reference to its own name. As I have mentioned before, the term 'Indonesia' has been concealed in all those political views. At this point, narratives, symbols and rituals that constitute a sense of mutual and national belonging are something that can possibly be shared with other nations. Freedom and liberation in political views are values attached by the users when they approach the idea of nation, not by plainly ascribing the mutual sense of community as a nation but also positioning nationalism in the global perspective. This is done by featuring ideas that represent the condition of marginalized groups of people that possibly live in separate geographical space but share the same vision of freedom, liberation and even rebellion. Every identity might experience the different sites of oppression, diverse ideological principles and each has to contribute to the very fundamental conception and vision of emancipation which are relevant to their unique characteristics. However, by posing the issue of self-sovereign in global digital media like Facebook, they all argue that this is an urge for all nations, especially those who still strive for liberation from colonial forces in all senses.

I agree with Nakamura's argument that chosen identities are not breaking the mold of unitary identity but rather shifting identity into the realm of the 'virtual' and it can definitely create and reproduce stereotypes as well (Nakamura, 2002; 4). Identity is truly traveling now, traversing the frontiers between the offline and the online screen. I also concur with Bhabha on his theory that postcolonialism will always operate through the dimension of time, history and space, both geographical

\footnotetext{
${ }^{1}$ www.nasional.kompas.com. Retrieved: 02-12-2009
} 
and political by positioning new media as a space through which activities by which new identities, new geographies, and new conceptualization of the world are fashioned and performed (Young, 2001; 66). Formulating national identity can no longer be done by simply drawing a strict line that physically separates one object from another. Even though national heritages are apparently materialized in tangible or natural matter and marked out by geographical borders that did not happen by accident rather were contested, defended and constructed (McLeod, 2000; 68), national identity has possibly been envisioned by positioning one's nationality among others, exercising the notion of differences as well as similarity.

I believe that the invisibility of national identity does not automatically mean that national identity has not been taken into account. Being promoted from an object of history to the rank of creators (Abdel-Malek in Brydon, 2000b; 829), the Orients should think how to call themselves. Living in the world called the Oriental, the resistance to the politics of Orientalism can be performed by asking what Said has asked in 'Oientalism Reconsidered' -who writes or studies the Orient, in what institutional or discursive setting, for what audience, and with what ends in mind? (Said in Brydon, 2000b; 848). Posing these questions will lead to a wide range of answers that convey a problem about how postcolonial identity (the Orient) can produce non-dominative and non-coercive knowledge without being trapped to think within the logic of colonialism.

\section{Religion, Nation and Multiple Images of the Orient}

When new media are believed promoting no boundaries in the physical world, the same thing also happens in the incorporeal realm where the border that constructs the basic conception of religion itself has been stretched out beyond the conventional principles. It is not my intention to say that before the reformation, Indonesian people were frightened to stand for what they believed. Yet it must be clearly recognized that every cultural phenomenon leads to significant changes in ways of thinking. I concur with Schaeffer (Schaeffer in Smith, 2006; 20) who claims that" If we are to understand presentday trends in thought, we must see how the situation has come about historically and also look in some detail at the development of philosophic thought-forms". I believe that the conception of the self will always be embedded by what the history has brought to the subjects and the way it shapes the actuality of identity in all notable moments. I will bring the historical context of Indonesians in order to show how this nation is very familiar with the tradition of violence even in the realm of religion. It needs to be done before understanding how new media, and Facebook in particular through the section of 'religious view', function as a break down that can potentially disrupt the dominance of tradition for having religious matter as a grounding of coercion.

Islam, Christianity, Catholicism, Budhism, and Hinduism are five official religions acknowledged by the Indonesian government. Other believers are prohibited to engage in religious practices or worship and also are not allowed to bring up any disciples or followers. In Indonesian context, the first of the five principles in Pancasila, the philosophical foundation of the Indonesian state, which is 'Believe in the one and only God' (Ketuhanan Yang Maha Esa) has established a strong interrelation between the State and religion. All believers are not merely convinced by the dogma to have faith in God but are also required by the State to confess one of six officially recognized religions. This first principle was initiated as an alternative to the creation of an Islamic state, even though there were many who were in favor of founding the state on the basis of the religion of the majority (Vickers, 2005; 118). With the endeavor to recognize the value of other religions and minority groups, the first principle was set up to guarantee the rights of all Indonesian citizens to hold any acknowledged religions. In fact, the use of the term 'official religion' (agama resmi) is still debatable until now.

In 1978 the government issued the circular letter of the Minister of Home Affair which stated that there were only five religions in Indonesia even though the higher constitution, the former Presidential Decision No. 1/Pn.Ps/1965 1/Pn.Ps/1965 recognized Konghucu as a valid religion together with the other five. As a consequence of this circular letter, all citizens were ordered to fill in the religion section in their National Identity Card (Kartu Tanda Penduduk /KTP) by choosing one of five religions. Konghucu was excluded until K.H Abdurrahman Wahid, the fourth Indonesian president, annulled this in 1978 and acknowledged Konghucu again as one of six official religions in Indonesia. Even though the 1945 Constitution does not explicitly state these six religions, it is still generally assumed that Indonesia recognizes only them which leaves out other forms of indigenous spiritualism. Until now, religious affiliation still needs to be listed by all Indonesian citizens in their National Identity Cards which brings many discrimination practices based on religious differences in reality.

There are multiple images of the Orient portrayed on the section of 'religious view' on Facebook which should not be oversimplified as they reflect the intricate concept of culture itself which. Its "differential and relativist" functions are precisely what is important (Clifford in O'Hanlon \& Washbrook in Brydon, 2000; 905). The absence of a unified identity is the most obvious feature displayed on Facebook and religious view is the section where the Orient is constantly performing their cultural differences, bringing any possible form of subversion, mockery and cynicism into play as an effort to deconstruct 
any single master narrative and reject all universal forms of cultural centralization. At this point, being modern or staying traditional may not be the main issue for the Orient. Rather what is at stake is the construction of new ways of exercising knowledge about oneself and the others. Facebook equally privileges the voices of indigenous individuals and gives space for the Orient to reinvent themselves in unpredictable ways.

The online religion emerges as a response to the call to deconstruct grand narratives. The word 'others' used by Nayarini Estiningsih when she defines her religious view on her Facebook account is quite provoking as it implies a distance, a separation from anything that has existed before. One intriguing statement is written by Muhammad Amin: 'Religion' and 'Atheism' are the same stupidity with different name whilst PennyRoyal Tea writes down 'Believe 1 God' for her religious view'. For many and nearly all people, cyberspace is a playful and sacred space at the same time. Imagination and vision about the self, others, society and nation are all penetrating this virtual terrain and showing the unstoppable transformation of reality and history. Social, political and religious institution are about to change by the power of free will, a will for interpretation and multiple production of identities. Satrya Wibawa passionately envisages that spiritual experiences are expected to happen in cyberspace when he says this appealing statement in his religious view: 'God is in Internet! Believe me'. All these users are reluctant to state or choose one of 'official' religions. As an alternative, they put forward their enthusiasm of playing part in the self-determination and taking advantage of Facebook that allows their identities to be embedded as unconventional towards religious views. Some of them still correlate their religious view with the existence (or extinction) of God to different extents whereas others prefer to approach religious matter quite unconventionally. How can one comprehend such words like 'agnostic', 'toujours fidele', 'progressive muslim', 'proud to be infidels...they shall enjoy freedom, democracy, art and rock music', 'esoteric', 'inheritance' (warisan), 'monyetism' ('monyet' means monkey) or 'samawi religions' (agama samawi) with no trouble at the first reading of subject's account on Facebook?

Some phrases might be relatively more familiar because they make use of concepts that are generally recognizable and highly allied with religious matter. Some labels are considered as unusual for naming a religion since they widen the very conception of what should be considered as religion, especially when the enduring religious traditions have habituated the followers to get familiarized only with major religious affiliation which are Islam, Christianity, Catholicism, Budhism and Hinduism. In her book 'Give Me That Online Religion', Brenda E. Braser has explored more than one million operating online religion websites. They encompass every major religious traditions in the world, most new religious groups and innumerable social movements that function as de facto religion for their follower (Braser, 2001; 6). This online phenomenon provides evidence on the aptitude of new media to promote an interreligious understanding. The challenge to traditional religion has been set up not only by modern religious institutions but also it is made possible by every single individual in the virtual space. This way narrative introduces an opposing point of view, perspective, consciousness to the unitary web of vision (Said 1978; 240). For me, the fundamental issues of human and social life are now under erasure since everyone starts asking the essence of being which in my opinion arguing that there is no essential being that can escape from the historically-cultural shift. All ideas are seeking for self-expression and new media overpoweringly endows individuals with an immense power to pose their incredulity toward meta-narratives.

If the religious freedom comes to be construed as the individual's right to worship any god or none at all (Tipton in Arjomand, 1993; 274), it does not automatically render the position of religion outside of public life. But if God is in Internet as said by Satrya Wibawa, then God must compete with the others positioned as the center of religion in the online world. Religion may still need God, but speaking of religious view, any corporeal matters or forms of knowledge can potentially catch the attention of a new devotee without being institutionally engaged. The way the internet fascinates its users may be the main reason why Satrya Wibawa argues that God (must be) in the Internet. Re-fashioning God and giving Him/Her the new look that goes well with face of the digital era can be the case here, but erecting boundaries that formerly existed between faith and knowledge is quite liberating for many people. Religious skepticism (a religion without religion) may be the product of postmodern religious faith which is not linked to any particular dogma, doctrine and denomination (Smith, 2006; 119). If Satrya Wibawa's statement should be considered as a radical view for bringing the Internet as the new sanctuary where everything that people believe in God are already provided by technology, how about the indigenous religions which actually exist in the Indonesian society? Do new media bring their existence back or make them present in Indonesian people's lives after prolonged concealment in nearly all media representations?

Indonesian government has chosen to call the indigenous Indonesian religion as 'aliran kepercayaan'. It is analogous with a cult which means that it is not acknowledged as a religion, but only as a spiritual practice that believes on the existence of God. Personal experiences and relationships between the followers and their God is the basis of the practice that combines different system of religious beliefs with mystical elements that are typical to local values among particular ethnicities. In some areas in Indonesia, there are existing indigenous beliefs, such as the 'Sunda Wiwitan' embraced by the 
community in Baduy, Lebak, Banten and also known as CIGUGUR religion (and there are several other names), 'Buhun religion' in West Java; 'Kejawen' in Central Java and East Java; 'Parmalin religion', an indigenous Batak religions; 'Kaharingan religion' in Kalimantan; 'Tonaas belief' in Minahasa regency, North Sulawesi; 'Tolottang' in South Sulawesi; 'Wetu Telu' in Lombok or 'Naurus IslandSeram' in Maluku Province. These indigenous religions are degraded as a doctrine of animism, pagan or just as a cult as I mentioned before. The religious matter had been exercised by the government as the instrument of oppression instead of being developed as national heritage.

I used my personal Facebook account to ask other users whether any of them write down the indigenous Indonesian religion or not in the 'religious view' section. None of my friends on Facebook responded positively. This implies different meanings. The users may not know what the indigenous Indonesian religions are or they choose not to relate with traditional values. It is easier to find various religious views which are not rooted in Indonesian ritual or tradition. The Orient occupies the virtual terrain and brings representational images posed by the West to trouble. This is the point of departure for the negotiation of the self, the process of destabilizing the firm construction of the Orient by progressively challenging any homogenous intellectual, cultural and political narratives.

If the essence of Orientalism is the ineradicable distinction between Western superiority and Oriental inferiority (Said, 1978; 42), does the formulation of contemporary religious view on Facebook point towards the idea of bringing the Orient closer to modern realities as a refusal to accept the binary distinction made by the West? When While Said says that everywhere among Orientalists there was the ambition to formulate their discoveries, experiences and insights suitably in modern terms $(1978 ; 43)$, I personally find out the paradox between the potential to break out from the stereotypes of the Orient and the tendency to intensify the constructed figure of the Orient. By realizing that the construction of binary positions was based on the imaginative vision about the Orient who is oddly different - unusual, fantastic, bizarre, irrational, extraordinary, or abnormal (McLeod, 2000; 44) - and that history is made by men, 'religious view' materializes power exercised by what has been called the Orients in order to give shape to the new material reality of the Orientals.

\section{REFERENCES}

Abdel-Malek in Brydon, Diana (ed), Postcolonialism: Critical Concepts in Literary and Cultural Studies, London \& New York: Routledge, 2000

Bassett, Caroline, 2007, The Arc and the Machine: Narrative and New Media, Manchester \& New York: Manchester University Press

Brasher, Brenda E, Give Me That Online Religion, San Fransisco: Jossey-Bass: A Wiley Company, 2001

Foot in Silver, David \& Massanari, Adrienne (eds), 2006, Critical Cyberculture Studies, New York \& London: New York University Press

Foucault in Dreyfus, Hubert L. \& Rabinow, 1982, Michel Foucault: Beyond Structuralism and Hermeneutics With an Afterword by Michel Foucault, Great Britain \& USA: THE HARVESTER PRESS LIMITED

Foucault, Michel, 1994, The Archaeology of Knowledge, London: Routledge

Fernandez, Maria, Postcolonial Media Theory, Art Journal 58: 3 (Autumn 1999)

Jenkins, Henry, 2009, Confronting the Challenges of Participatory Culture: Media Education for the 21st Century, USA: MIT Press

Kitley, Philip, 2000, Television, Nation and Culture in Indonesia, Ohio USA: University Center for International Studies Loomba, Ania, 1998, Colonialism/PostColonialism, London \& New York: Routledge

McLeod, John, 2000, Beginning PostColonialism, Manchester \& New York: Manchester University Press

Muller, Arjen, 2004, Understanding Media Theory, Rotterdam: NAi Publishers

Nakamura, Lisa, 2002, Cybertypes: Race, Ethnicity and Identity on the Internet, New York: Routledge

Philpott, Simon, 2000, Rethinking Indonesia: Postcolonial Theory, Authoritarianism and Identity, London \& New York: MACMILLAN PRESS LTD

Ricoeur in White, Hayden, 1987, The Content of the Form: Narrative Discourse and Historical Representation, Baltimore \& London: The Johns Hopkins University Press 
Said, Edward W, 1978, Orientalism, Harmondsworth, Middlesex: England: Penguin Books Ltd

Sen, Krishna \& Hill, David T, 2000, Media, Culture and Politics in Indonesia, New York: Oxford University Press

Smith, James K.A, 2006, Who's Afraid of Postmodernism?: Taking Derrida, Lyotard and Foucault to Church, Michigan: Baker Publishing Group, 2006

Tipton in Arjomand, Said Amir (ed), 1993, The Political Dimensions of Religion, USA: State University of New York Vickers, Adrian, 2005, A History of Modern Indonesia, Cambridge, UK: Cambridge University Press

Washbrook in Brydon, Diana (ed), Postcolonialism: Critical Concepts in Literary and Cultural Studies, London \& New York: Routledge, 2000

Young, Robert J.C, 2001, PostColonialism: An Historical Introduction, USA \& UK: Blackwell Publishing 